\title{
THE IMPLEMENTATION OF THE SYLLABUS WHICH CONTAINS LOCAL WISDOM AT X GRADE SMKN 1 PAYAKUMBUH
}

\author{
Normalasari, Veni Roza, Genta Sakti \\ Islamic State Institute (IAIN) of Bukittinggi \\ Sarinormala96@gmail.com, Veniroz_501@yahoo.com, gentasakti64@gmail.com
}

\begin{abstract}
The research was due to the problem. The teacher had implemented the syllabus which contained local wisdom Minangkabau, but when the researcher saw the English textbook, the researcher found that there was no local wisdom included. This study used descriptive qualitative method as the paradigm in this research. The finding of this research reveals that the teacher included local wisdom in various ways. The first was when in a part of the introduction, the teacher included local wisdom through giving the motivation to the students, giving advice to students. The second was in a core activity the teacher included local wisdom through giving explanation before, through giving exercises. And the last in a part conclusion,the teacher included local wisdom through concluding the lesson and asking the students about the local wisdom related to a lesson. The result, the teacher implemented local wisdom values Minangkabau for increase character personality students.
\end{abstract}

Keywords: Syllabus, Local Wisdom

\section{INTRODUCTION}

In an education system, there are many things that support the learning process in the classroom especially syllabus. A syllabus is learning for a particular groups of subjects and themes includes competency standards, basic competencies, subject matter to learn, and learning resources. Thus, the syllabus is one of the factors to achieve or to develop students' competency by the teacher in the processing of learning in the classroom. According to Suyono (2015), syllabus is a framework or summary of the main points of learning material, lecture material or a text. Syllabus is needed in the learning process at school is carrying out within a predetermined period of time.

Furthermore, a syllabus is a foundation for the activity of the lesson in the school. Without a syllabus, the teacher will be difficult to implement a subject at each meeting. Because of that, when the teacher wants to teach in the classroom, they must see the way or the rule of how deliver the subject to the students. In conclusion, without a syllabus in the school, the teacher will be difficult to know what is the competency that the students need.

In addition, the teacher is a professional educator with the main task of educating, teaching, guiding, directing, evaluating students at the levels of formal education, basic education, and secondary education. Therefore, the teacher is a professional in learning at school needs a tool to protect the teacher performances the syllabus itself. According to Putri (2018), learning is the process of interaction between students and teacher and the source to learn in environment. Then, According to Arifmiboy (2014), the teacher as facilitator very influence to students includes sociality, culture, or economy.

In addition, local wisdom is part of a culture not separated from the community itself. According to Mugmacon (2012), local wisdom is basic knowlegde gained from living in 
balance with nature; it is related to culture in the community which is accumulated and passed on. Thus, local wisdom is basic knowledge about the life nature and related to the culture.

Furthermore, one the ways in includes a local wisdom through a lesson in the classroom. Local wisdom as a values to students in social life. According to Syafitri (2019), value is used as a director in social life because each behavior has certain values.

Furthermore, According to Setiadi (2019), local wisdom is a custom and tradition that has been carried out by community groups for generation, local wisdom still holds up by certain indigenous people in certain areas.

Research problem in this research was the researcher found that there was no local wisdom included. This study used descriptive qualitative method as the paradigm in this research. Literature review in this research, the first about the nature of the syllabus which contained a) the definition of the syllabus, b) the component of the syllabus, c) the purposes of the syllabus, d) the function of the syllabus and e) the advantages of the syllabus. The second is the nature of local wisdom, which contained a) definition of local wisdom, b) the function of local wisdom, c) the function of local wisdom and d) the forms of local wisdom. This research had one research question like how does the teacher implements the syllabus which contains local wisdom in the process of English teaching?

\section{METHOD}

This research is a kind of descriptive research. According to Gay (1990), descriptive research involves collecting data in order to answer the question concerning the current status of the subject of the study. It means that, if the researcher conduct descriptive research, the researcher must collect the data and try to describe it based on the current status found the researcher. Then, according to Suryabrata (2011), descriptive is research that is used to describe situations or conditions. The researcher conducted through descriptive research, the researcher must collect the data and try to describe it based on the current status found by the researcher.

In addition, according to Mahmud (2011), descriptive research is a study that is strived to another or observe problems systematically and accurately about the facts and the nature of certain objects. The setting of this research is in the school of SMKN 1 Payakumbuh. Data sources in this research was from an English teacher and students in $\mathrm{X}$ grade SMKN 1 Payakumbuh.

The data of this research collected through observation. The researcher acted as a participant observation. In this observation, the researcher seat in the classroom to see how the teacher implementation syllabus which contains local wisdom.The researcher used observation to get information about how is the teacher implemented the syllabus which contains local wisdom in SMKN 1 Payakumbuh. The observation arranged with the name of the teacher who teaches English language, observation, place, time, and items to be observed. The researcher checklist for each item that occurs during observation. According to Margono (2007), the cheklist is an arrangement that is done by the researcher through columns by giving the check sign in every item that is to observe. 
After the data was collected by observation, the next step is analyzing the data. Data analysis is a process to look and organize the data system that is obtaining through the observation. So it can be easy to understand and present as the findings of others. In analyzing the data, According to Sugiyono (2010), firstly, data reduction; the researcher made a summary of the data, selecting the subject matters, focus on the research aspects, look for themes and patterns and reduce unnecessary things. Secondly, display the data, the researcher shows the data in narrative type. It is the researcher who writes the result of the research by explaining the data to know-how is the implementation of the syllabus which contains local wisdom at the first grade of SMKN 1 Payakumbuh. Finally, the researcher has concluded the data about the implementation of the syllabus which contains local wisdom at SMKN 1 Payakumbuh.

\section{FINDINGS AND DISCUSSION}

The result of this research that teacher implemented local wisdom values Minangkabau for increase character personality students. The data collected by observation, the next step is analyzing the data. Data analysis is a process to look and organize the data system that is obtaining through the observation. So it can be easy to understand and present as the findings of others.

The aim of this research was to find how the teacher implements the syllabus which contains local wisdom in the processing of teaching at X grade SMKN 1 Payakumbuh. This research was conducted in SMKN 1 Payakumbuh in Bonai Indah Payakumbuh. The researcher focused on this research in OTKP major, this major had one English teacher. In addition, based on several observations that were done by the researcher, the researcher found some ways that the teacher used to implement the syllabus which contains local wisdom.

In a teaching activity especially in the introduction, in apart at the teacher was greats to the students, here the teacher did not include the values of local wisdom Minangkabau to students. The teacher only greets the students with greetings Assalamu'alaikum. This was corroborated by the data of several observations that the researcher has done. The conclusion was that at the teacher stage greeting students, the teacher did not incorporate the values of local wisdom at all.

In the preliminary stage, the teacher gave motivation to students so that students are motivated to learn. Here, there are a number of ways that teachers did. First, here the teacher was included the values of local wisdom to students by explaining to students the sincerity of something obtained. This was corroborated by the evidence of observations made by the researcher. The teacher has applied the values of local wisdom by saying we must be sincere with what we get, we must be grateful, actually, if we are sincere we will get more than what we expect.

The second was at the stage of providing motivation to students, so students are motivated to learn, the way that teachers did was to instill the values of character to children, namely through telling children when someone did something here it looks how our characters. Did we have the character of the person responsible or not. Not only that, when people were walked, we can already assess the character's personality. This was supported by observation data that the researcher did. 
In conclusion on the part of the teacher provides motivation for students so students are motivated to learn, here the teacher has applied some values of local wisdom to students, the first was the value of sincerity and the value of a person's personality characters.

In addition, in the introduction section precisely the teacher gave an explanation of the learning objectives before starting learning, at this stage the teacher did not include the values of local wisdom to students. The teacher only communicated the learning objectives before starting the learning. In conclusion was that in the introduction section precisely the teacher gave an explanation of the learning objectives before starting learning, here the teacher did not apply the values of local wisdom at all.

Furthermore, in the introduction, precisely in the part where the teacher conveys the scope of the material in accordance with the discussion they will learn, here the teacher did not include the values of local wisdom at all. The teacher only conveys the scope of the material they will learn to students. The conclusion was that inthe introduction, precisely on the part of the teacher, the scope of the material in accordance with the discussion they were learned, the teacher did not incorporate the values of local wisdom at all to students.

Furthermore, at the core of learning, especially in the observing section, namely at the teacher part facilitating students to observe the discussion they learn, at this stage the teacher did not include the values of local wisdom to students, this was supported by observation data that researcher did. In conclusion, was that at the observing stage especially in the teacher facilitating students to carry out the process of observing the discussion they learn here the teacher does not include the values of local wisdom at all

In addition, at the core of the learning section precisely the teacher was guided students to observe the discussion they are learning, at this stage the teacher did not incorporate the values of local wisdom to students. This was supported by observation data that the researcher did. In conclusion, in the core section precisely the teacher was guided students to observe the discussion they are learning, at this stage the teacher does not incorporate the values of local wisdom in the learning process.

Furthermore, at the core of the learning section precisely the teacher was asked to students to observe the objects that have been determined, at this stage the teacher did not apply the values of local wisdom to students. Here the teacher only tells students to observe something. This was supported by observation data by the researcher. The conclusion was based on observations made by the researcher that the teacher did not apply the values of local wisdom precisely at the core of learning at the teacher stage asking students to observe objects that have been determined.

Furthermore, at the core of learning precisely at the stage students make observations through reading. At this stage, the teacher did not apply the values of local wisdom at all. This was supported by some observational data that the author did. So the conclusion was at the core of learning precisely on the part of students observing through reading, here the teacher did not apply the values of local wisdom in the teaching process.

In addition, at the core of learning especially in observing sections where students are made observations through listening. At this stage, the teacher did not apply the values of local wisdom to students at all. This was supported by some observational data that researchers did. So the conclusion at the observing stage was precisely that students make 
observations through listening, here the teacher did not apply the values of local wisdom in the teaching process to students.

Furthermore, in the observing section precisely at the stage of students observing through listening, here the teacher did not apply the values of local wisdom in the teaching process. Here supported by observational data that researchers did. So, the conclusion was at the observing stage, precisely on the part of students observing through listening, here the teacher did not apply the values of local wisdom at all, this was supported by observational data that researchers did.

Furthermore, inthe observing section precisely at the stage students are made observations through seeing, at this stage the teacher did not apply the values of local wisdom. At this stage, the teacher only asked the students to observe. This was supported by observation data that the researcher was done. So the conclusion was that the teacher did not apply the values of local wisdom at the student stage of observing through seeing.

In addition, at the core of learning precisely at observing precisely at the stage students made observations. In these sections, the teacher did not apply the values of local wisdom. This was supported by observation data by the researcher was done. So the conclusion is at the stage of students making observations through watching, at this stage the teacher did not apply the values of local wisdom in the teaching process to students.

Moreover, in the core part of learning precisely in the questioning section. In the questioning section mainly the teacher was facilitated to students to do the questioning process, at this stage the teacher was applied the values of local wisdom. The way the teacherwas applied to students was by asking students about the relationship with local wisdom. The value of local wisdom contained herein was to instill character values to students. The way was to give examples to students through the second verb, for example with the word borrowed. Here the teacher was given an example of how to borrow money from people, it should not be hardened if people did not want to lend it to not be angry. This was hooded by observation data that researchers did.

In conclusion, was the teacher applied the values of local wisdom in the core part of learning precisely in the Questioning section especially in the Teacher section facilitating students to carry out the questioning process.

Furthermore, at the core of learning precisely in the Experimenting section especially in the teacher part facilitating students to carry out the process of gathering information related to the discussion they are learning. At this stage the teacher applies the value of local wisdom by reading to students about the tribe tagak suku paga suku, tagak kampuang paga kampuang, tagak nagari paga nagari, and tagak bangso paga bangso.

In addition, at this stage, the way the teacher was applied Minangkabau local wisdom values was by inserting destructive words that the local wisdom values contained in it are patriotism, nationalism, and have a big soul. Here the teacher said how did we play the tribe, country, and nation. As well as how we respect patriotism in protecting tribes, countries, and nations. This was supported by observational data that researchers did.

The conclusion was that in the core part of learning precisely in the experimenting section especially the teacher was facilitated to students to carry out the process of gathering information related to the discussion they are learning, the teacher incorporates several values 
of local wisdom namely the value of patriotism, the value of nationalism and the value of big soul.

In addition, at the core part of the learning process, in the experimenting section, especially in the part of students doing the related experimental activities instructed by the teacher to try about the discussion they were learned. At this stage, the teacher applied the values of local wisdom by asking students to associate with the learning material they are learning. This was supported by observation data that the researcher did. At this stage, the value of local wisdom applied was the value of a person's personality and professional character. At this stage, the teacher gave convey the value of local wisdom through examples when people play volleyball. It shows how they dress, how they accept losing and winning and so on.

The conclusion was that at the core activity stage, especially at the experimenting section at the student stage conducting the related experimental activities instructed by the teacher by trying to discuss what they are learning the teacher was applied the values of local wisdom by giving examples to students. Then the values of local wisdom that the teacher applied are personality character values and professional values. This was supported by observational data that the authors did.

Furthermore, at the core of learning at the student stage of conducting experimental activities through group work. In this section, the teacher has applied the values of local wisdom by linking the recount text with the kato pusako in the syllabus. Kato pusako tagak suku paga suku, tagak kampuang paga kampaunag, tagak nagari paga nagari dan tagak bangso paga bangso.

In addition, local wisdom values that are applied are big-hearted, personality characteristics. So the conclusion is at the core of learning precisely at the stage of students was conducted experiments through group work, here the teacher has applied the values of local wisdom such as personality characteristics and big spirits.Moreover, in the core part of learning at the stage students conduct experimental activities through demonstration. At this stage, the teacher did not apply the values of local wisdom in the teaching process. So the conclusion was that the teacher did not apply local values in the core part of learning, especially at the stage of students conducting experiments through demonstration.

In addition, was at the core of learning, especially at the stage of students conducting experiments through imitating the form/motion associated with the discussion they are learning. At this stage, the teacher did not apply the values of local wisdom at all. So the conclusion is at the core of learning precisely on the part of students conducting experiments through imitating forms, movements related to the discussions they learn, the teacher does not apply the values of local wisdom to students.

Furthermore, in the core part of learning, especially at the stage students were conducted experiments through trying something based on the objectives to be achieved in learning. At this stage, the teacher applied the values of local wisdom by asking students to link the links between the values of local wisdom that they have learned. The value of local wisdom applied here was socialized, that was, humans cannot live without other creatures. So the conclusion is the teacher applies local wisdom at the stage of students doing experiments through trying something based on the objectives to be achieved in learning at this stage the teacher applies the value of local social wisdom. 
Moreover was at the core of learning, especially at the stage students were conducted experiments through reading in addition to the main book they have such as student worksheets. At this stage, the teacher did not apply the values of local wisdom at all. So the conclusion was at the stage of conducting experiments through reading other than the main book they have such as student worksheets, the teacher does not apply the values of local wisdom

In addition, at the core part of learning in the Associating section especially at the teacher stage facilitating students to carry out the process of gathering or associating related discussions they learn. At this stage, the teacher did not apply at all about the values of local wisdom so the conclusion at this stage was the teacher did not apply the values of local wisdom in the teaching process.

Furthermore, at the core of the learning process at the communicating stage especially at the teacher stage facilitating students to carry out the communication process related to what they want to achieve. At this stage, the teacher applies the values of local wisdom by communicating or conveying directly the values of local wisdom such as self-character, sincerity, and also self-preservation. The way the teacher was applied it is by giving students an explanation of the meanings of local wisdom itself. So the conclusion is at the teacher stage facilitating students to carry out the communication process related to what they want to achieve, the values contained in the stage are self-character, sincerity and also selfpreservation.

In addition, in a a core of learning, especially in the teacher was asked students to present their work. At this stage, the teacher did not include Minangkabau's local wisdom values. So the conclusion is that at the teacher's core learning stage the teacher asks students to present their work, the teacher did not include the values of local wisdom at all.

Furthermore at the closing part of learning. The teacher incorporates the values of local wisdom by concluding that we must be able to take care of ourselves, be sincere in doing something, then take care of our courtesy to people. At this stage, the value of local wisdom applied is sincerity, self-preservation, courtesy, and courtesy. So the conclusion is at the closing stage of learning, the teacher was concluded about local wisdom to students.

Moreover, at the closing phase, especially on the part of the teacher was gave the opportunity for students to ask questions related to the subjects they have learned. At this stage, the teacher did not apply the values of local wisdom to the students at all. So the conclusion is that in the closing part of learning, especially at the teacher stage gives the opportunity for students to ask questions related to the subjects they have learned, at this stage the teacher did not apply the Minangkabau local wisdom values at all.

In addition, closing part of learning especially at the teacher asking students to do homework assignments then praying and the teacher saying hello, the teacher does not include at all the values of local wisdom when the teaching process. The teacher only asks students to do the assignment at home and then the teacher closes the learning by saying greetings namely Assalamualaikum.

So the conclusion was in the closing section of learning, especially in the teacher asking students to do assignments at home then praying and the teacher saying greetings, at this stage the teacher did not enter the values of local wisdom at all. 


\section{CONCLUSIONS AND SUGGESTION}

The purpose of this research is to know how the teacher implement syllabus which contains local wisdom. based on research question about how the teacher implementation syllabus which contains local wisdom at $\mathrm{X}$ grade SMKN 1 Payakumbuh.The teacher implement syllabus which contains local wisdom in various way. The teacher includes the local wisdom in English lesson can be in the first that the teacher come to the class, when the teacher begin to open the lesson, through advice, through the teacher give exercises to the students, through the character, through the teacher explain the subject to lesson, and through the teacher concluded the lesson.

In addition, the second teacher implement local wisdom in processing of teaching was direct and indirect such as with said direct kato Pusako Tagak suku paga suku, Tagak kampuang paga kampuang, tagak nagari paga nagari, tagak bangso paga bangso. Indirect that the teacher included local wisdom such as with gived advice to the students such as ikhlas because the values by the kato pusako not only Tagak suku paga suku, Tagak kampuang paga kampuang, tagak nagari paga nagari, tagak bangso paga bangso, but also patriotisme, Nasionalisme, ikhlas, pemaaf, berjiwa besar.

Furthermore, through included the local in processing of teaching from teacher to students, it can make knowledge the students to their culture increased and they can pretend the culture their ancestor for generation to generation. Through included loval wisdom in a lesson, the students can know how to manage their self until did not came to forbidden their life.In conclusion, the teacher implementation syllabus which contains local wisdom in the first that the techer begin to start the lesson, the middle of the lesson, and in conclusion in processing of teaching.

Based on the result of the result of the research, it was found that some problem which happened in looking for teacher implementation syllabus which contains local wisdom for $\mathrm{x}$ grade at SMKN 1 Payakumbuh. The researcher would like to suggest as follow: the first for practitionersit more better to put the religies and attitude value to students. For policy maker, to further improve the work of the work through being passed down to the nation's generations. The last for further researchIt is hoped for the next researcher to do the research in other settings to have variation research as the researcher assumes that this research is conducted in different places. It will give a different result.

\section{REFERENCES}

Arifmiboy, A. (2014). Perbedaan Individu Dan Perkembangan Kognitif Anak Serta Implikasinya Terhadap Pembelajaran, 3(2). Retrieved from https://doi.org/10.30630/polingua.v3i2.26

Gay, L. R. (1990). Educational Research: Competencies For Analysis And aplication. New York: Meril.

Putri, H. M. (2018). Analisa Kebutuhan Silabus Bahasa Inggris I Mahasiswa Perbankan Syariah Berbasis ESP, 2(2). Retrieved from http://ejournal.iainbukittinggi.ac.id/index.php/febi/article/view/663

Mahmud. (2011). Metode Penelitian Pendidikan. Bandung: CV Pustaka Setia. 
Margono, (2007). Metode Penelitian Pendidikan. Jakarta: PT. Rineka cipta

Mugmacon, M. R. (2012). Knowledge and Local Wisdom: Community Treasure, 2(13). Retrieved from www.ijhssnet

Setiadi, K. (2019). Pengaruh Kearifan Lokal Dan Kecerdasan Spiritual Terhadap Perilaku Peserta Didik, 1(4). Retrieved from https://doi.org/10.30603/jiaj.v4i1.850

Sugiyono. (2010). Metode penelitian kuantitatif, kualitatif dan R\&D. Bandung: Alfabeta.

Suryabrata, S. (2011). Metodologi Penelitian. Depok: Raja Grafindo Persada.

Suyono, (2015). Implementasi Belajar dan Pembelajaran. Jakarta: PT. Remaja Rosdakarya

Syafitri, W. (2019). Empowering Muslimah Students Awarenes About Their Costume: Designing English Material for Islamic Higher Education, 3(2). Retrieved from http://dx.doi.org/10.30983/humanisme.v3i2.2526 